\title{
Valuing groundwater: A practical approach for integrating groundwater economic values into decision making - A case study in Namibia, Southern Africa
}

\author{
C Bann ${ }^{1 *}$ and SC Wood ${ }^{2}$ \\ ${ }^{1}$ Economics for the Environment Consultancy Ltd (eftec), 16 Percy St, London, UK, W1T 1DT \\ ${ }^{2}$ UK Atkins, Woodcote Grove, Ashley Road, Epsom, Surrey, UK, KT18 5BW
}

\begin{abstract}
Groundwater provides a range of services to people in Southern Africa; however, the benefits provided by these services are often not fully appreciated and factored into decisions about groundwater management and use. After outlining briefly the importance of groundwater in the region and the pressures facing groundwater, this paper discusses how economic valuation can help improve its management. The main focus of the paper is the presentation of the practical 5-step economic valuation methodology that has been developed as part of the Southern African Development Community (SADC) Groundwater and Drought Management Project. This methodology can be generally applied to groundwater management issues across the SADC region. The methodology is based upon an ecosystem services approach which considers all the potential services that groundwater provides, which can result in improvements in human welfare. These services include provisioning services such as water for domestic use, agriculture and industry; regulating services such as the recharge of surface waters and carbon storage benefits; and cultural services such as the tourism associated with wildlife at groundwater-fed watering holes. The methodology incorporates a 2-tiered valuation approach. The Tier 1 valuation is based on market pricing and value-transfer approaches and can provide an initial view of the economic value of a resource in a particular use. A value-transfer tool has been developed, which allows the user to select from a menu of the currently available transfer values for use in an assessment. A Tier 2 valuation requires more detailed primary studies and may be required following a Tier 1 assessment where more certainty in decision-making is required. The methodology has been tested at 4 pilot sites in the region. An example of the application of the SADC groundwater-valuation methodology in Namibia is presented in this paper. The paper concludes with recommendations for the development of groundwater valuation in the region. Emphasis is placed on training, the commissioning of more groundwater-valuation studies and the need for more scientific research to facilitate the valuation of groundwater-regulating services.
\end{abstract}

Keywords: economic value, groundwater, ecosystem services, SADC

\section{Background}

Atkins and the Economics for the Environment Consultancy (eftec) have recently completed an 18-month study to develop a practical groundwater-valuation tool for the Southern African Development Community (SADC). This study was funded by the World Bank and managed by the United Nations Office for Project Services (UNOPS) on behalf of SADC, under its Groundwater and Drought Management Programme (GDMP). The need for this research was driven by the fact that while the development and management of water resources in SADC member states has traditionally focused on surface waters, increasing aridity and limited surface water resources have increased the dependence on groundwater for both domestic and commercial water needs. At the same time, groundwater faces a range of threats from increasing population and industrial development, including over-abstraction and aquifer pollution. These threats are compounded by the effects of drought and climate change and are impacting the security and sustainability of water resources and resulting in the degradation of groundwater-dependent ecosystems (GDEs). Under the study the following activities were undertaken:

This paper was originally presented at the International Conference on Groundwater: Our Source of Security in an Uncertain Future, Pretoria, 19-21 September 2011.

* To whom all correspondence should be addressed.

용 +44 7553 38-0163; e-mail: camille.bann@envecconsulting.com a high-level characterisation of the groundwater resource across the SADC and the pressures that it faces; an extensive literature review on groundwater valuation; development of a practical groundwater-valuation methodology, which includes a value-transfer tool to facilitate high-level assessments; the testing of the groundwater-valuation methodology at 4 sites in the region; production of a user guide to accompany the methodology; and an analysis of future priorities and needs to develop groundwater valuation in the SADC.

\section{The importance of groundwater in the SADC}

\section{Groundwater use within SADC}

About one-third of the people in the SADC member states live in drought-prone areas. In the driest part of the region, groundwater is the primary source of: drinking water for the human population and livestock; irrigation for agriculture; and water supply to industry. It is also essential for wildlife and hence is fundamental to the tourism industry in these dryland areas (SADC, 2010). For the arid and semi-arid areas within the SADC (Botswana, Namibia and parts of most of the other SADC member states), groundwater is often the only source of water and is used for a range of purposes. For example, in Namibia groundwater is used for urban water supply (e.g. Windhoek, Swakopmund and Walvis Bay), irrigation (Stampriet aquifer, Grootfontein/Tsumeb aquifer), mining and rural water supply. In the humid areas (including large areas of Angola, Democratic Republic of Congo, Madagascar, Malawi, 
South Africa, Zambia and Zimbabwe), groundwater is mostly used for rural water supply and for mines in isolated areas.

The dependence on groundwater and its importance (value) in the SADC region is set to increase over the coming decades as water resources face increasing pressures related to the growth in populations and economies of the region, pollution and climate change. If the region becomes more drought-prone under a changing climate, the use of groundwater, which is generally a more drought-resistant resource than surface water, will be extremely valuable.

\section{Pressures facing groundwater resources in the SADC}

The pressures referred to above can generally be categorised either as threats to quantity or quality although both are often experienced together.

Reduced recharge due to long-term drought or climatechange-driven changes in spatial distribution of precipitation can result in a reduction in the quantity of groundwater available for abstraction or support to surface waters and wetland habitats. However, these outcomes can also be caused by overabstraction of groundwater from an aquifer.

Increased population and economic development inevitably result in an increase in the generation of waste products and, if disposed of inappropriately, these have the potential to contaminate groundwater resources and lead to degradation and economic costs.

Within the SADC region, potential sources of groundwater contamination are numerous and include activities in the domestic, agricultural, mining, industrial and urban sectors. The widespread use of on-site sanitation in rural and urban parts of the region can cause contamination of shallow aquifers and in fractured or karst bedrock with pathogens and nitrates. The increase in commercial agriculture, particularly horticulture, in some parts of the region has led to the contamination of some aquifers with fertiliser-derived nutrients (e.g. in the Kafue Valley in Zambia and the Kutuma and Sinthumule districts of Venda, South Africa). Mining activities have, in some cases, led to the contamination of aquifers with metals and other contaminants as well as depleting the groundwater in aquifers to the detriment of other users. Pollution from mineral processing has led to the contamination of aquifers with arsenic in Zimbabwe and heavy metals and sulphates in shallow groundwater systems in Botswana (SADC, 2010).

\section{Why value groundwater?}

There are 2 reasons why it is important to value groundwater in the SADC:

- Raise awareness of the importance and varied use and services provided by groundwater

- Improve decisions on the management and use of the groundwater resource.

Raising awareness: Identifying, and where possible valuing, the full range of services provided by groundwater can assist in raising the profile of groundwater in the region and contribute towards its sustainable management. These services include the provision of water for domestic, agricultural and industrial use, but also less well appreciated services such as the recharge of surface waters and flood-prevention services. Table 1 provides a typology of the full range of groundwater 'ecosystem services'. This typology adopts an ecosystem services framework, which explicitly recognises that ecosystems and the biological diversity contained within them contribute to the individual and social wellbeing of humans. Ecosystem services are categorised into: provisioning services which are associated with goods provided by the ecosystem such as water supply; regulating services which refer to processes such as climate regulation, modification of flow processes (e.g. flood control) and the dilution of pollutants; and cultural services which relate to the non-material benefits obtained from groundwater and GDEs, for example, through tourism and educational and spiritual experiences.

Improving decisions: Groundwater valuation is important as an input into decisions on its use and management. The use of groundwater as a scarce resource entails tradeoffs - its use in one activity (e.g., agriculture) implies that it is not available for another use (e.g., domestic supply or to support ecosystems of high conservation value). An understanding of the economic value of groundwater in different uses and under different management options can promote its sustainable management, help allocate water to its highest value use, and inform policies on the provision of water as a basic human need.

Groundwater valuation and economic appraisal can help answer important questions fundamental to the sustainable management of the groundwater resource, for example:

- What is the best groundwater project, policy, management option from a set of alternatives (i.e., which option maximises net benefits)?

- What are the costs of unsustainable groundwater use?

- Is a project or policy worthwhile?

- How much does groundwater contribute to the economy?

- What sectors are most dependent on groundwater?

- How much should be spent on groundwater management practices?

- Is there a case for actions to conserve groundwater?

- What is the appropriate level of a groundwater user tariff?

- What level should a payment for ecosystem service (PES) be set at?

- What uses should abstracted groundwater be allocated to?

- What is the value of environmental damages?

- What scale of compensation for damage is justified?

\section{A practical methodology for groundwater valuation}

A practical methodology for integrating the economic values of groundwater services into decision making in the SADC has been developed and tested. It entails 5 key steps as presented in Fig. 1.

Step 1 provides background on the groundwater site under study and the context for the economic valuation and assessment. This step involves building up an understanding of the groundwater resource - its physical characteristics as well as the uses and pressures it faces - and determining how economic valuation can help inform key policy or management decisions about the use of groundwater at the site.

Step 2 defines the scope of the assessment. Under Step 2, the key groundwater ecosystem services at the site, such as water supply, surface-water recharge benefits, and reduced flood risk, are identified through a qualitative assessment and the analyst determines whether the data and resources exist to value them. This step also determines what type of assessment framework would be appropriate. The most straightforward type of 


\begin{tabular}{|c|c|c|}
\hline \multicolumn{3}{|c|}{$\begin{array}{c}\text { Table } 1 \\
\text { Potential groundwater services and benefits }\end{array}$} \\
\hline $\begin{array}{l}\text { Ecosystem } \\
\text { service } \\
\text { category }\end{array}$ & Service & Benefit / outcome \\
\hline \multirow{6}{*}{$\begin{array}{l}\text { Provisioning } \\
\text { services }\end{array}$} & \multirow[t]{4}{*}{ Water supply } & Public water supply \\
\hline & & Private / community water supply \\
\hline & & Agriculture \\
\hline & & Industrial abstraction \\
\hline & Habitat for hypogean species & Species diversity and potential genetic/scientific value \\
\hline & Sink/source of energy & Energy provision \\
\hline \multirow{7}{*}{$\begin{array}{l}\text { Regulating } \\
\text { services }\end{array}$} & $\begin{array}{l}\text { Recharge to surface waters (rivers, lakes, } \\
\text { springs, wetlands, transitional waters) }\end{array}$ & $\begin{array}{l}\text { Protecting the benefits of surface water for consumptive and non-con- } \\
\text { sumptive use (e.g. water abstraction, recreation and tourism, non-use) }\end{array}$ \\
\hline & Flood risk regulation & $\begin{array}{l}\text { Flood risk reduction (protection of property, agricultural land, human } \\
\text { lives) }\end{array}$ \\
\hline & Sink for atmospheric carbon dioxide & Carbon capture \\
\hline & Dilution of pollutants & Reduced impact of contaminants \\
\hline & Attenuation of pollutants & Reduced impact of contaminants \\
\hline & Prevents subsidence & Avoidance of subsidence \\
\hline & Sustains habitats & Reduction of irrigation requirement \\
\hline \multirow{2}{*}{$\begin{array}{l}\text { Cultural } \\
\text { services }\end{array}$} & Biodiversity non-use & Biological diversity, species, habitat \\
\hline & $\begin{array}{l}\text { Tourism, spiritual, religious, educational } \\
\text { experiences }\end{array}$ & Tourism, spiritual, religious, educational experiences \\
\hline
\end{tabular}

\begin{tabular}{|c|c|c|}
\hline & $\begin{array}{l}\text { Step 1: } \\
\text { Characterise the }\end{array}$ & $\begin{array}{l}\text { 1a. Develop a conceptual understanding of the physical characteristics of the } \\
\text { groundwater system, e.g., its size, boundaries, inflows and outflows }\end{array}$ \\
\hline & $\begin{array}{l}\text { determine the } \\
\text { context for the } \\
\text { assessment }\end{array}$ & $\begin{array}{l}\text { 1b. Define the issue facing the groundwater resource, i.e., what are the main uses of } \\
\text { and threats to the groundwater, who is being affected and how }\end{array}$ \\
\hline & & $\begin{array}{l}\text { 1c. Define the decision-making context, e.g., demonstrating the importance of the } \\
\text { groundwater site, setting priorities, project/policy analysis, legal damage assessment, } \\
\text { or establishing a basis for a charge (pricing) }\end{array}$ \\
\hline & $\begin{array}{l}\text { Step 2: } \\
\text { Define the scope } \\
\text { of the economic } \\
\text { assessment }\end{array}$ & $\begin{array}{l}\text { 2a. Select ecosystem services for valuation: } \\
\text { - } \quad \text { Undertake qualitative assessment of ecosystem services } \\
\text { - } \quad \text { Determine data availability (scientific/quantitative) } \\
\text { Determine which ecosystem services are to be valued }\end{array}$ \\
\hline $\begin{array}{l}\text { Figure } 1 \\
\text { Integrating economic }\end{array}$ & & $\begin{array}{l}\text { 2b. Define type of assessment, e.g., valuation of groundwater in its current use or } \\
\text { allocating groundwater between different uses }\end{array}$ \\
\hline $\begin{array}{l}\text { groundwater decision- } \\
\text { making }\end{array}$ & & 2c. Quantify the baseline and impacts of future changes in groundwater use \\
\hline & Step 3: & 3a. Tier 1 Valuation: Valuation using market prices and value transfer \\
\hline & $\begin{array}{l}\text { Undertake } \\
\text { valuation of } \\
\text { ecosystem } \\
\text { services }\end{array}$ & $\begin{array}{l}\text { 3b. Tier } 2 \text { Valuation: If more detailed evidence is required following a Tier } 1 \\
\text { valuation, commission primary economic studies using production function, } \\
\text { revealed preference or stated preference approaches }\end{array}$ \\
\hline & $\begin{array}{l}\text { Step 4: Analysis } \\
\text { of valuation } \\
\text { evidence }\end{array}$ & $\begin{array}{l}\text { 4a. Aggregation } \\
\text { 4b. Sensitivity analysis } \\
\text { 4c. Cost-benefit analysis } \\
\text { 4e. Distributional analysis }\end{array}$ \\
\hline & $\begin{array}{l}\text { Step 5: } \\
\text { Report and }\end{array}$ & $\begin{array}{l}\text { 5a. Reporting: Including identification of priorities for future valuation, and data } \\
\text { requirements to undertake more detailed primary studies if needed }\end{array}$ \\
\hline & & $\begin{array}{l}\text { 5b. Develop dissemination tools, e.g. policy briefs that use non-technical language, } \\
\text { technical reports for practitioners, and media releases. }\end{array}$ \\
\hline
\end{tabular}


assessment framework is a valuation of a groundwater resource in its current use, but cost-benefit analysis (CBA) is recommended where possible to understand the trade-offs associated with different groundwater uses and management.

Step 3 values the groundwater ecosystem services identified in Step 2 as being significant and possible to value, given available data and resources. The methodology provides for a 2-tiered valuation approach. The Tier 1 valuation allows a relatively quick and less data-intensive route to providing an initial assessment of the groundwater resource, which can be used to inform decisions and/or to indicate if and where more certainty in the evidence base is required. The Tier 1 valuation approach is based on the use of market price and value-transfer approaches. Where possible, market price approaches should be used. Where market prices do not exist, or non-market values are known to be large, value transfer may be used. A value-transfer tool has been developed, which presents available unit transfer values for groundwater ecosystem services in the SADC, along with guidance on their application. This value-transfer tool is based on an extensive literature review of studies from the region, and provides transfer values for the following ecosystem services - public water supply; private/ community water supply; agricultural abstraction; industrial abstraction; attenuation of pollutants; and recharge to surface water. In some cases surface water estimates have been used as proxies for groundwater values due to the extremely limited number of groundwater-specific studies. The transfer values may also be used as benchmarks against which new values based on market-price approaches or other methods can be compared. Given that the majority of transfer values relate to provisioning services, for which market-price approaches can be applied, this comparative use of the value-transfer tool is considered to be highly relevant. A Tier 2 assessment involves the use of a more detailed primary valuation approach involving targeted, site-specific economic research. It is only undertaken following a Tier 1 assessment if better evidence is required and should be managed by an experienced economist.

Step 4 analyses the valuation undertaken in Step 3. In all cases unit values need to be aggregated based on the population, or by the number of hectares, benefiting from the groundwater ecosystem services to derive total values. Sensitivity analysis is also recommended in all cases to highlight to decision makers the confidence that may be attached to the values. If a CBA of alternative groundwater-use scenarios is being undertaken, different options or scenarios will need to be defined and compared, and discounting of annual values and one-off costs over an appropriate timeframe will be required to derive net present values (NPVs). A distributional analysis is recommended. This is used to identify who wins from current and potential groundwater use and who loses. This information can be used to develop mechanisms to compensate those who lose from a particular groundwater use or allocation.

Step 5 involves reporting and disseminating the results of the valuation and assessment.

\section{Application of the groundwater-valuation methodology}

The SADC groundwater-valuation methodology presented above was piloted at the Kuiseb, Swakop and Omaruru alluvial aquifers in Namibia. Water from these aquifers is predominately used for urban water supply, uranium mining and small-scale agriculture. Groundwater also plays an important role in supporting GDEs in the area. Uranium mining places significant demand on water resources and is the main industry in the area. It is currently experiencing an upsurge as a result of the growing interest in nuclear energy both within Africa and further afield.

The case study illustrates how the economic value of different water supply options (groundwater or seawater desalination) can be investigated to support water resource management decisions. It should be noted that the data and assumptions utilised in the case study are based upon a high level deskbased literature search and the resulting values are for illustrative purposes only. The application of the 5-step groundwatervaluation methodology is described below.

Step 1a: Develop a conceptual understanding of the physical characteristics of the groundwater system. The area covers 3 ephemeral river catchments and associated alluvial aquifers that are situated on the desert west coast of Namibia: the Kuiseb, Swakop and Omaruru catchments. There are 4 main urban settlements in the study area comprising the coastal settlements of Walvis Bay, Swakopmund and Hentiesbaai (with a combined population of around 87000 ), and the inland mining town of Arandis (with a population of around 4000 ). Due to the harshness of the environment, the remaining area is very sparsely populated. It is estimated that the sustainable yield of the alluvial aquifers of these 3 river catchments is $32.8 \mathrm{M} / / \mathrm{d}$ $\left(32.8 \times 10^{6} \ell / \mathrm{d}\right)(\mathrm{MME}, 2010)$.

Step 1b: Define the issue facing the groundwater resource. Demand for water within the area already exceeds the available freshwater resources and with the anticipated expansion of uranium mining, pressures on water resources are set to increase. The main water-resource options in the area are groundwater and seawater desalination. With the groundwater resources already fully committed, development plans need to take account of the potential economic and environmental impacts of further development of water supplies.

The existing uses of the groundwater within the study area include:

- Public water supply for indigenous, non-indigenous and visitor populations

- Rural domestic water supply and livestock watering on communal farms

- Water supply to Inara melon harvested by Topnaar indigenous people

- Process and potable water for mining operations

- Water supply to natural vegetation along river corridors

- Springflow to the groundwater-dependent components of Sandwich Harbour Ramsar site which is a coastal wetland in the Kuiseb lower catchment

Step 1c: Define the decision-making context and how the valuation evidence can assist decision making. It is evident that an economic analysis of different groundwater-use scenarios would help clarify the tradeoffs between uses and inform policy decisions on groundwater management in the area.

Step 2a: Select ecosystem services for valuation based on a qualitative assessment of the services provided, available data and resources to undertake the assessment. Following a literature review, it was determined that the groundwater 


\begin{tabular}{|c|c|c|c|c|c|}
\hline \multicolumn{6}{|c|}{$\begin{array}{c}\text { Table } 2 \\
\text { Unit values obtained for ecosystem serv }\end{array}$} \\
\hline $\begin{array}{l}\text { Ecosystem } \\
\text { service }\end{array}$ & Component & Valuation method & \begin{tabular}{|l|} 
Benefit/ \\
cost
\end{tabular} & Unit value & Source \\
\hline \multirow{4}{*}{$\begin{array}{l}\text { Industrial } \\
\text { abstraction } \\
\text { (mining) }\end{array}$} & $\begin{array}{l}\text { Pipeline conveying water from } \\
\text { wellfield to mine }\end{array}$ & Market prices & Cost & USD $1.5 \mathrm{M} / \mathrm{mile}$ & Mesa Water (2011) \\
\hline & $\begin{array}{l}\text { Desalination of water (including } \\
\text { plant, operation) }\end{array}$ & Market prices & Cost & $\begin{array}{l}\text { ZAR } 10.6 \mathrm{M}-\mathrm{ZAR} 12.6 \mathrm{M} \text { per } \\
\text { M } / \mathrm{d} \text { (capex); ZAR } 3.3-\text { ZAR } \\
4.0 \text { per } \mathrm{m}^{3}(\mathrm{OPEX})\end{array}$ & $\begin{array}{l}\text { Swartz et al. } \\
(2006)\end{array}$ \\
\hline & $\begin{array}{l}\text { Pipeline conveying water from } \\
\text { desalination plant to mine }\end{array}$ & Market prices & Cost & USD $1.5 \mathrm{M} / \mathrm{mile}$ & $\begin{array}{l}\text { Mesa Water } \\
(2011)\end{array}$ \\
\hline & $\begin{array}{l}\text { Value added by water to uranium } \\
\text { production per } \mathrm{m}^{3}\end{array}$ & Market prices & Benefit & $\begin{array}{l}{ }^{1} \mathrm{NAD} 52.7 \text { per } \mathrm{m}^{3} \text { water }(1995 \\
\text { prices })\end{array}$ & NDWA (2004) \\
\hline \multirow{3}{*}{$\begin{array}{l}\text { Public water } \\
\text { supply }\end{array}$} & $\begin{array}{l}\text { Desalination of water (incl. plant, } \\
\text { operation) }\end{array}$ & Market prices & Cost & $\begin{array}{l}\text { ZAR } 10.6 \mathrm{M}-\text { ZAR } 12.6 \mathrm{M} \text { per } \\
\text { M } / \mathrm{d} \text { (capex); ZAR } 3.3-\text { ZAR } \\
4.0 \text { per } \mathrm{m}^{3}(\text { OPEX) }\end{array}$ & $\begin{array}{l}\text { Swartz et al. } \\
(2006)\end{array}$ \\
\hline & $\begin{array}{l}\text { Pipeline conveying water from } \\
\text { desalination plant to towns }\end{array}$ & Market prices & Cost & USD $1.5 \mathrm{M} / \mathrm{mile}$ & $\begin{array}{l}\text { Mesa Water } \\
(2011)\end{array}$ \\
\hline & Livelihood/health of population & $\begin{array}{l}\text { Not valued as benefit } \\
\text { assumed to be the same } \\
\text { across all scenarios } \\
\text { whether from ground- } \\
\text { water or desalination } \\
\end{array}$ & Benefit & $\mathrm{n} / \mathrm{a}$ & $\mathrm{n} / \mathrm{a}$ \\
\hline $\begin{array}{l}\text { Agriculture (and } \\
\text { associated rural } \\
\text { domestic supply) }\end{array}$ & $\begin{array}{l}\text { Gain/loss of livestock farming } \\
\text { (and associated farms) }\end{array}$ & Value transfer & $\begin{array}{l}\text { Benefit } \\
(+ \text { ve }) / \text { Cost } \\
(-v e)\end{array}$ & $\begin{array}{l}\text { NAD } 1.21 \text { (2000 prices) to } \\
\text { NAD } 2.69 \text { (1999 prices) value } \\
\text { added per } \mathrm{m}^{3} \text { water }\end{array}$ & $\begin{array}{l}\text { MacGregor et al. } \\
(2000) \text {; Lindgren } \\
(1999)\end{array}$ \\
\hline $\begin{array}{l}\text { Biological } \\
\text { diversity, } \\
\text { species, habitat }\end{array}$ & Existence/loss of Ramsar site & Value transfer & $\begin{array}{l}\text { Benefit } \\
(+v e) / \text { Cost } \\
(-v e)\end{array}$ & USD 214/ha (2000 prices) & WWF (2004) \\
\hline
\end{tabular}

${ }^{1} N A D$ - Namibian dollar

ecosystem services requiring valuation were: public water supply, private water supply, agricultural water supply, industrial water supply, biodiversity non-use (in relation to springflow to the Ramsar site) and cultural use (in relation to groundwater use by the indigenous tribes).

Step 2b: Determine the type of assessment. A CBA of alternative groundwater use and water-supply options for uranium mining was selected as a means of demonstrating the tradeoffs involved and informing sustainable management options for the aquifers.

Step 2c: Quantify the groundwater service and for scenario analysis quantify the impact on ecosystem services of any predicted change. For each of the groundwater services identified for valuation in Step 2a, components and quantities associated with the following 3 theoretical development scenarios were identified:

- Scenario 1: In addition to the 3 existing mines, 4 new mines are constructed and mining is allocated the entire sustainable yield of the alluvial aquifers; the remaining mining demand is met by seawater desalination; public water supply is dependent on desalination; and the groundwater services provided to the GDE, farming and Topnaar livelihoods are lost.

- Scenario 2: In addition to the 3 existing mines, new mine development is constrained to the sustainable yield of the alluvial aquifers (i.e. 2 mines); public water supply is therefore dependent on desalination; and the groundwater services provided to the GDE, farming and Topnaar livelihoods are lost.

- Scenario 3: The GDE, farming and Topnaar livelihoods are maintained using groundwater; the balance of sustainable groundwater yield is allocated to public water supply and all mining water demand is met by seawater desalination.
Step 3a: Tier 1 Valuation and Step 4a: Aggregation. Quantities (e.g. populations, water demands, cultivated areas, wetland areas) were estimated for each of the services identified for valuation and for each of these, unit values were obtained either from market price data or from the value-transfer tool as detailed in Table 2. The unit values were adjusted to 2010 United States dollar (USD) prices and aggregated using the identified quantities to obtain total values for each service.

Step 4b: Cost-benefit analysis and Step 4c: Sensitivity analysis. Table 3 presents the total NPV of the 3 theoretical development scenarios. The range of values presented for each scenario illustrates the result of undertaking basic sensitivity analysis on the component unit values.

\begin{tabular}{|c|c|c|}
\hline \multicolumn{3}{|c|}{$\begin{array}{c}\text { Table } 3 \\
\text { Results of scenario and sensitivity analysis from } \\
\text { Namibian case study }\end{array}$} \\
\hline Scenario & $\begin{array}{l}\text { Total net present value in USD (\$) } \\
\text { (discounting at } 10 \% \text { over } 25 \text { years) }\end{array}$ & $\begin{array}{l}\text { Rank (in order } \\
\text { of the most } \\
\text { economically } \\
\text { beneficial) }\end{array}$ \\
\hline Scenario 1 & $\begin{array}{l}\text { USD } 1297 ; 228 ; 165 \text { to USD } 1 \\
301 ; 811 ; 449\end{array}$ & 1 \\
\hline Scenario 2 & $\begin{array}{l}\text { USD } 1123 ; 890 ; 604 \text { to USD } 1 \\
128 ; 473 ; 888\end{array}$ & 2 \\
\hline Scenario 3 & $\begin{array}{l}\text { USD } 1024 ; 718 ; 756 \text { to USD } 1 \\
029 ; 302 ; 040\end{array}$ & 3 \\
\hline
\end{tabular}

The high-level valuation suggests that the economic value of using groundwater for uranium mining outweighs the economic losses to other groundwater services under a 'maximum mining' scenario. However, it was not possible to estimate the cultural economic value associated with the dependence of the Topnaar population on groundwater. Furthermore, the environmental 
costs associated with desalination plant discharges were not included. These impacts are very site-specific and would require more comprehensive research to facilitate appropriate valuation. Inclusion of such values is likely to reduce the difference in the NPV between scenarios and could change the ranking.

Step 4d: Distributional analysis and Step 5a: Reporting. A high-level distributional analysis demonstrates that the rural and indigenous populations (approximately 20\% of the total population) are the cost bearers under Scenarios 1 and 2 and only become beneficiaries under Scenario 3. The type and number of beneficiaries under Scenarios 1 and 2 are more difficult to determine as this depends upon the complexities of how profits from commercial uranium mining ultimately filter into the local population. Further investigation would be required to characterise and quantify these impacts.

\section{The way forward}

This study provides a baseline in terms of the data and capacity currently available to undertake groundwater valuation in the SADC region. Against this baseline the steps needed to develop work in this area in the future have been prioritised as summarised below.

The literature review revealed that only 5 groundwaterspecific valuation studies have been undertaken in the SADC region. This very low number of studies highlights the need to undertake more primary studies. The case studies undertaken for the project were generally executed at relatively well-studied sites and were based on readily available information. They were also undertaken primarily to test the methodology and therefore have used default estimates and assumptions, which would need further refinement in order to be used in decision-making. There is a need to start to generate evidence on the benefits of sustainable groundwater management at other, less well-studied sites through longer term research studies. Priority areas of study include: studies of ecosystem services for which no transfer values are available (e.g. provisioning services such as industrial abstraction and the provision of a sink or source of energy and all groundwater regulating services); key policy areas where valuation work is yet to be undertaken such as the economic costs of pollution, contamination and saline intrusion; and studies in countries where no estimates currently exist. This would provide the SADC with a more complete repository of transfer values to be used to inform policy decisions. New studies should therefore be undertaken with value transfer in mind and ensure that information influencing the use of estimates in a value transfer is carefully reported. Studies should be focused on common issues and uses across the region in order to maximise their future transferability.

The valuation of the groundwater ecosystem services is restricted by the scientific evidence on the extent and function of these services, and how a change in their quality or quantity will translate into changes in the environment and hence the economy. Without a clear scientific definition and quantification of the service, it is not possible to undertake the valuation. For example, scientific evidence is required in order to make progress on the valuation of groundwater regulating service (e.g. recharge of surface waters, flood-risk regulation, sink for atmospheric carbon, attenuation of pollutants, and prevention of subsidence). This emphasises the need for interdisciplinary research efforts to ensure a smooth transition from the quantification of the impact (by scientists and planners) to the monetisation of this impact by economists.
Spatial factors are very important in determining the value of most groundwater ecosystem services given that ecosystem services are context dependent in terms of their provision and their associated benefits and costs. Therefore site-specific studies that build in key spatial features influencing the supply and demand of an ecosystem service are required for truly reliable valuation estimates. Spatial factors include temperature, rainfall, topography, quality, quantity, substitutes, population and socioeconomic factors. Incorporation of spatial factors in groundwater-valuation studies in the SADC in many cases requires the generation of data. The use of Geographical Information Systems (GIS) in valuation is developing as a means of incorporating spatial factors in ecosystem valuation. Groundwater valuation in the SADC could build on existing SADC GIS initiatives in groundwater vulnerability mapping and the mapping of groundwater-dependent ecosystem services.

Training in groundwater valuation and appraisal is important to encourage more valuation work, to ensure that this work is executed to an acceptable standard, and to facilitate the understanding of the valuation findings by decision-makers and others. A range of training initiatives is recommended targeted at the different groups who play a part in groundwater valuation, management and decision making, such as economists, policy makers, implementation agents, the private sector and technical and scientific experts. Medium to longer term priorities include the development of scenario analysis for alternative groundwater uses building in existing climate-change predictions and other relevant trend information, the development of green accounts for groundwater and consideration of the option value of groundwater (this relates to any premium that people may be willing to pay to ensure the option of being able to use groundwater in the future).

\section{References}

LINDGREN A (1999) The Value of Water: A Study of the Stampriet Aquifer in Northern Namibia. Master's Thesis. UMEA University, Sweden.

MINISTRY OF MINES AND ENERGY (MME) (2010) Strategic Environmental Assessment for the central Namib Uranium Rush. Ministry of Mines and Energy, Windhoek, Republic of Namibia.

MESA WATER (2011) Panhandle Project. Mesa Water, Texas, USA. URL: http://www.mesawater.com/FAQs/default.asp (Accessed 14 February 2011).

MACGREGOR J, MASIREMBU S, WILLIAMS R and MUNIKASU C (2000) Estimating the economic value of water in Namibia. Proc. $1^{s t}$ WARFSA/Waternet Symposium: Sustainable Use of Water Resources. 1-2 November 2000, Maputo, Mozambique. URL: http://www.waternetonline.ihe.nl/index.php?option $=\mathrm{com}$ wrapper\&view $=$ wrapper\&Ite mid=230 (Accessed 13 July 2011).

NAMIBIA DEPARTMENT OF WATER AFFAIRS (NDWA) (2004) Draft Technical Summary of Water Accounts for Namibia. Ministry of Agriculture, Water and Rural Development, Namibia.

SOUTHERN AFRICAN DEVELOPMENT COMMUNITY (SADC) (2010) Groundwater in SADC. SADC Groundwater website.URL: http://www.sadc-groundwater.org/groundwater.php (Accessed 13 July 2011).

SOUTHERN WATER (2009) Southern Water Water Resources Management Plan 2010 - 2035. URL: http://www.southernwater. co.uk/pdf/environment/waterResources/FWRMP_Main\%20Rept $\% 20$ combined Sep $\% 2009 \% 20$ Final.pdf (Accessed 3 June 2011).

SWARTZ CD, DU PLESSIS JA, BURGER AJ and OFFRINGA G (2006) A desalination guide for South African municipal engineers. Water SA 32 (5) 641-647.

WORLD WILDLIFE FUND (WWF) (2004) The Economic Values of the World's Wetlands. Report prepared with support from the Swiss Agency for the Environment, Forests and Landscape (SAEFL), Gland/ Amsterdam. URL: www.panda.org/downloads/freshwater/wetlandsbrochurefinal.pdf (Accessed 13 July 2011) 